\title{
學術集談會演說要旨
}

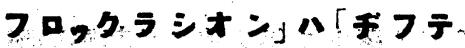

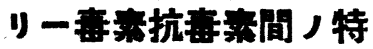
異性反産ナリャ(抄錄)

$$
\text { 寺 尾 秀三 }
$$

從來デフテリー抗毒血清及ビ 毒素，評㵋八 專ラ動物能习藉りテ第ス外途ナカリシ如クナ ルが 1922 年. Ramon が Calmette, Nicolle 等

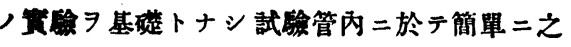
ヨ测定スル方法习案出七り而シテ此，際抗毒 素毒素,中和現象トシテ現出スル絮狀反㗹 7 Lafloculation 卜稱淦來，免疫反應卜全》意 味习異ニナストコロノ一新特異反㮣ナリト提 唱セり两來追試研究缩出シ其/使用㑯值及ビ 其ノ本馝ニッキ議未ダ決定セザル所ナリ。

余八其，使用㵋值 ロックラシォン現魚ナルモ八 八果シテ Ramon 唱フル如り特暴性ナルヤ否ヤニッキ研究シ 夷ノ如キ結果习得タリ。

1）細谷宮田氏細菌毒素精製法或へウキル スデッター氏酳素精製法二準㨜 シテ「デフテ リ一毒素/精製习試ミ更二該精製毒素 オリン吸著法等ニヨリ可及的夾雜物 $习$ 除去ス

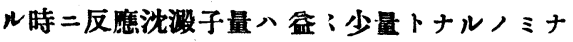
ラズ䇤性ナキ「フラクチオン」二於テモ該反焦 ノ起ルコトヨ珰メタリ。

2) ヂフテリー毒素二「タカヂアスターセ ヨ作用セシメテ動物二對シテ全ク無毒トナレ ル毒素液二於テモ原毒素卜同ジ著明ナル該反 磼习起スヨ認メタリ。

3) デフテリー毒素二承醏酸或八純酒精 加へ生ズル沈檓，毒力八非常二娍弱スル $=モ$

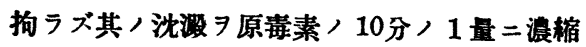
ンテ沈降セシムルトキハ武騟管內抗體結合力 八原毒素丁度 10倍トナリテ毫竟處置セザル 嗉素卜抗鰽結合性能力八同ジモノナルコト
知レり然ルニ之ヨ以テ免疫セル動物，免度管

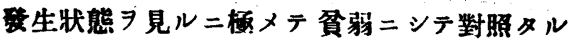

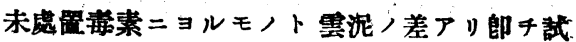

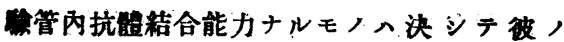
ラモンノ云フ如キ免度元性习意味スルI:dikator デナイコトヨ彗明セり。

4) 木精 及ビ上清ニモ該反應生ズル 知りヌアセト

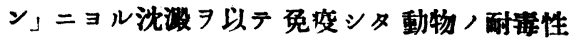
卜其，試駼管內抗體結合力卜何等一致 ルヨ镒明セり。

5）ヂフテリー血清卜異種毒素タル志賀赤 䓶菌毒素. 破傷風毒素。猩紅熱ヂックトキシ ン(マルタレブイョン培養) 等卜立搌二該反鹰 起ルコトヨ知りラモン，特異性反應ナル根㨜 八間違デアッタコトヨ磪メタリ。

6）ヂフテリー毒素卜志贺赤莉抗毒血清間 こモ該反應現出スルコト习䧳明セり。

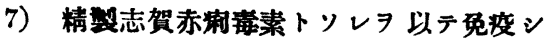
タル抗毒山羊血清間ニハ「フロックング現奥习 呈セザリシ事习登明シ。ラモンノ「フロック シォン現象ナルモノ八全ク特異性毒素卜無開 係ナルコト习立教セり。

8）ヂフテリー血清 ヨ波體空氣 ヨ以テ凍結 融解习絽返ヘシ抗毒儥，減弱セシニモ拘ラス 「フロックング」八未處置原血清卜全ク同槏ナ。 ル反應狀態习呈スルコトラ證明セリ。

9） ヂフテリー毒素卜志賀赤湖抗毒血清間

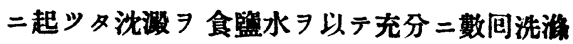
七ル後其/沈測 食篮水二溶解シテ海晖二注射スルトキ八毒素 ノ一部八沈测ト結合シテ居ルコトラ知り「ギ フテリー毒素抗毒素間，沈淑，結合 二於テ モ中和過剩/毒素ノ一部八同樣二沈没卜結合 スル可能性アルベキヨ想像シ. H.Schmidt， 提唱セル T. A. F. 免疫が一部, 追試者 $=$ 『 


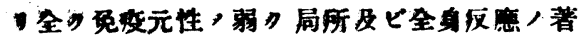

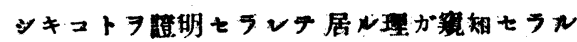
模二思へレッ。

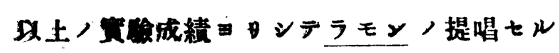

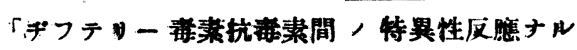

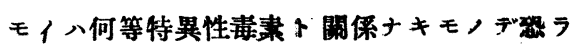
ク八其八培地タル「マルタンブイシシ」分解 産物ト夫レ二對スル抗軆間，非特县性反焦ナ ルぶク且ッ「ヂフテリ一血清卜異程毒素间，

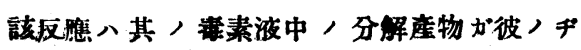
フテリー」毒素/結合ト類似七ル開係デアル 如タ考フルノが究當デアラウト思ハレル。

・要スルニ「ギフテリー毒素抗毒素間ノ「 ロックランォン現象》Toxin-Antitoxin-Reaktion デナイト云フ結詥 續シタイト考フ。

\section{腔内細菌特二乳酸禅菌及ビ 「エンテロコッケン」ノ矿究}

\section{第 1 報 初生兒腟內菌, 㸴究} 小島三 郎 真 柄 正 直 小豆烟久治

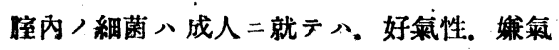
性. 及ビ通性踭氮性ノ總テ，部類二於テ極又 テ多數ノ種類ノ存スルコト八周知ノ事賽ナル が. 初生兒腔內, 細菌二關シテ八. 其, 研究 缺クル所多シ。特二我が國二於テハ此ノ方 面文獻ヨ見ルコトスラ稀ナル狀態二在り。 故三余等八初生兒腟內, 細菌 7 生後逐時的或 逐日的二檢索シ. 其八種類及ビ出現八時間 的關係 $ヨ$ 明ニシタリ。而シテ臆內細菌中様氣 性 =屬スルモノニ八. 病原的或 八胵生物學 上. 特二重要ナル意義 二此處ニ於テハ「タロッチ寒天本板上二發有 得ルモ, 郎千通性婙氣性及ビ好氣性, モノ= 就テ述ベントス。

先ツ腟生物學上極丈テ意義アリト考へラル ルデーデルラインノ桿菌 (乳酸桿菌) =就テ述

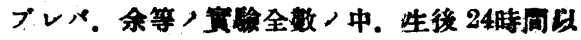

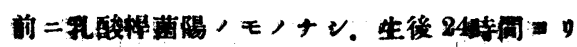

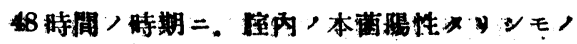

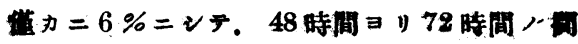

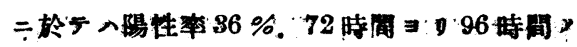
間二於テ菌陽性ノモノ一埇80\%卜ナル。面。 テ 96 時間 ョり 120 時間，間二於テ八 $96 \%$ 卜 ナり。更二120時間以後二及心心總テ，初生 兒䃥内二乳酸桿菌 $\ni$ 認ムルニ至ル。而ンテ其

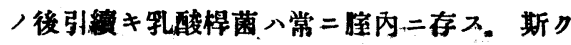
人如り乳酸桿菌、生後 24時間以後ニ至レバ初 生兒腟內二徐々二出現シ始ムルモノナルモ. 72 時阙以後二至ツテ初メテ策現スルモ，最モ 多》、又最モ迤キモノモ。120時間後二至レ バ凡テ發現シ終ルモノナリ。

次二通常非病原性ナルモ時二病原タリ得ル 所ノ大腸菌及ビ「スタとロコックン」二就テ見 $N=$. 是等，菌モ办生後 12 時間以前二於テへ 拄内二棲息スルコト決シテナシ。然レトモ生 後 24 時間ヨ渦グレバ急激二剫現シ。全例數 $70 \%$ 於テ之 7 胃火. 面シテ. 生後 48 時間 二於テ八. 全數二於テ. 是等, 菌方認ムル 至ル. 然ル二乳酸桿菌が旺盛二出現シ始ム必 生後 72 時間ノ時期二至レバ。是等八菌〉陽性 率、 $88 \%$ トナy.96時間ニシテ $59 \%$ 下り。 120 時間二テモ亦 $60 \%$ 示ス. 然レドモ生得 6 日7 日ト經ルニ從ツテ再ビ是等, 菌が增大 スルガ如キ傾向习見ル。

郎千初生兒胵八. 生後 12 時間以丙八縃對無 菌期ニシテ. 24 時間ヨリ72 時間迄八第三清㴶 度期郎チ殆ンド總テニ於テ雜菌ノミヨ存シ。 72 時間 $\exists 1150$ 時間迄八比較的第一清潔度期 郎千大多數二於テ乳酸桿菌ノミヨ認ムルモ， ニシテ. 大約 150 時間以後二至レバ第二清潔 度期 7 呈シ.引續キ此, 狀態 $ᄏ$ 繼䏆スルモノ ナリ。

前記ノ細菌)他二從來記載 7 見ザリシ「エ ンテコロックン」ヨモ脭內 $=$ 殆ンド毎常贸ム ルモノナルガ. 此/菌，出現，時間的關係八。 大腸菌ト站行スルモノナリ。病原性極メテ强 
キアストレフトコックン」の全ク之ヨ見ザリキ。

是等䋖テ”細菌，寉內出現ノ徑路二關シテ 八. 分娭時初生兒ガ鱏產道二於テ細菌习㗪

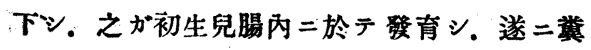
便卜共二排洒サレ. 續イテ外陰部二附著シ. 逐二煊内二侵入スルモ，、如シ。
例へバ余等ノ賽驗ニ於テモ賞便中，乳酸桿 菌出現率卜. 臸內同菌陽性率ト 7 比較スルニ. 翼便二先二現ハル、モ，50\%ニシテ同時二現 ヘル、モノ残リノ50\%ナリ。而シテ腟二先: 現ヘル、モノヨ全ク見ザル事賽モ亦此,假定 ヨ毫書キスルモノ、如シ。

\section{新文獻抄錄}

\section{魚油中ノ Vitamin-A =開}

\section{スル知胃}

P. Karrer, R. Morf u. K. Schaepp.

Helvetica Chimica Acta Vol. 14 (1931); V (1030) u. VI (1431)

とラメ」ノ一種 Hippoglossus , 肝胵 erolaether $=$ テ抽出シタル油ヨ战化シ. 其不

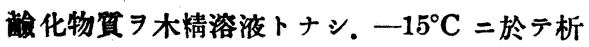
出スル多量，Sterin 類习除去シ. Carr-Price 反憵(Antimontrichlorid-Reaktion) $5000-6000$ C. L. D. 單位 $\exists$ 有スル淡褐色, 油 7 得。更二 コレヨ固形炭酸及ビ Aceton, 混合冷却劑二 テ $-60^{\circ}=$ ナテテ處理シ次二陶土ニョル Fraktionierte Adsorption $\ni$ 行ヒ遂 $=$ Carr-Price 反應 10.500 C. L. O. 單位 7 有 スル. 强力 Vitamin-A Präparat ' $\exists$ 得»。本品八淡黄色. 常䁅ニテハ油狀, 液體. 在來, 有機溶媒二可 溶. 空氣中二テ酸化セラル。良觶肝油，C.
L. O. 數八 1. Carotin $>700$. 日本, Bios terin 入 1200 ナルョリ. 本品八鮕肝油ノ約 1 萬倍 Carotin /約 15 倍. Biosterin >約 89 倍强力デアル。V. Euler 八本 Präparat 7.

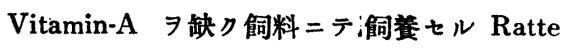

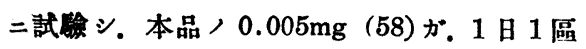
二對スル Normal 正常 Znwachswirkung, Grenzdosis デアルコトヨ證シタ。コノ實驗二 ヨリ. 今迄一般二八承認サレテ居ラナカッタ. Zuwachswirkung ト Carr-Price 反倠卜ハ殆 ド本行ニ進ムトイフコトが確カニサレタ。化 學的二八Ozon 分解 $=ヨ$ り Gerbnsäure $\ni$ 得 ルコトョリ Vitamin-A 、Carotin 誘導體ナ ルぶシト推定シ. 更二 Acetat, p-Nitrobenzoesäure-ester $\exists ッ \eta リ$. 又元素分析, 結果 $\mathrm{C}_{20} \mathrm{H}_{30} \mathrm{O}$ 又、 $\mathrm{C}_{22} \mathrm{H}_{3} \mathrm{O}$ ナル式二相當スル值 ヨ得タ. 以上及ビ其他, 賽驗, 結果ョリ. Vitamin-A，構造式トシテ次ノ $2 ッ \ni$ 呈シテ 居ル。

( I )

( II )<smiles>CC(C=CC1=C(C)CCCCC1(C)C)=CC=CC(C)=CCO</smiles><smiles>CCCCCCCCC=CC=CC=C(C)C=CC=CC=CCO</smiles> 